\title{
In Vitro Digestibilities of Summer Forages Utilized by the Rivière George Caribou Herd
}

\author{
STEEVE D. CÔTÉ
}

\author{
(Received 6 February 1997; accepted in revised form 22 October 1997)
}

\begin{abstract}
The Rivière George caribou herd (northern Québec-Labrador, Canada) is thought to be regulated by forage limitations in its summer range. In such a situation, digestibilities of plants may strongly affect the diet choice and physical condition of animals. In vitro dry matter disappearance (IVDMD) of the most important summer forages of the Rivière George caribou herd was determined during fermentation periods of 12, 24, and $48 \mathrm{~h}$ using rumen fluid collected from a Holstein cow. IVDMD values for Cyperaceae (Eriophorum angustifolium and Carex rariflora), and shrubs (Betula glandulosa and Vaccinium uliginosum) collected in July and August were higher for long fermentation periods (48 h) than for shorter ones (12 and $24 \mathrm{~h}$ ). Plants collected in early summer were also more digestible than those collected in late summer. Contrary to my prediction, both Cyperaceae were more digestible than the two shrubs in mid-July. However, no difference occurred in early August. The fermentation period did not affect the IVDMD of lichens; maximum digestibility was attained after $12 \mathrm{~h}$. Alectoria ochroleuca and Cetraria spp. were more digestible than Cladina rangiferina, Cladina stellaris, and Stereocaulon paschale, likely because of their lower fibre content. These results suggest that the preference of caribou for Cladina spp. is not based on digestibility, but probably on the fact that these species are abundant in the Rivière George area. Variations in IVDMD seem to be explained by plant phenology, because longer fermentation periods were necessary to attain a high level of digestibility as summer progressed. Plant digestibility alone cannot explain caribou summer diet. Other variables such as plant constituents (e.g., protein) and relative abundance must also be considered.
\end{abstract}

Key words: caribou, Cyperaceae, digestibility, fermentation, foraging ecology, in vitro, lichens, nutrition, Québec, Rangifer tarandus

RÉSUMÉ. Il a été suggéré que l'abondance du troupeau de caribous de la rivière George (Québec nordique-Labrador, au Canada) était régulée par la disponibilité de nourriture dans les habitats d'été. Dans un tel système, la digestibilité des plantes peut affecter de façon importante le régime alimentaire et la condition physique des animaux. La disparition in vitro de la matière sèche (DIVMS) des principales espèces végétales composant la nourriture estivale des caribous de la rivière George a été déterminée durant des périodes de fermentation de 12, 24 et 48 heures, à l'aide de jus de rumen provenant d'une vache Holstein. Les valeurs de DIVMS des cypéracées (Eriophorum angustifolium et Carex rariflora) et des arbustes (Betula glandulosa et Vaccinium uliginosum) récoltés en juillet et août étaient plus élevées pour de longues périodes de fermentation (48 heures) que pour de courtes périodes (12 et 24 heures). Les plantes récoltées tôt durant l'été étaient aussi plus digestes que celles récoltées tard. Contrairement aux prédictions, les deux espèces de cypéracées étaient plus digestes que les deux espèces d'arbustes à la mi-juillet, mais pas au début août. La durée de fermentation n'a pas affecté la DIVMS des lichens, le maximum de digestibilité étant atteint après 12 heures. Alectoria ochroleuca et Cetraria spp. étaient plus digestes que Cladina rangiferina, Cladina stellaris et Stereocaulon paschale, probablement parce que leur contenu en fibres était plus faible. Ces résultats suggèrent que la préférence des caribous pour les espèces de Cladina n'est pas basée sur leur digestibilité mais probablement sur le fait que ces espèces sont abondantes dans la région de la rivière George. Les variations de DIVMS observées semblent s'expliquer par la phénologie de la végétation, des temps de fermentation plus longs étant nécessaires pour atteindre une digestibilité élevée vers la fin de l'été. La digestibilité des plantes seule ne peut donc expliquer le régime alimentaire du caribou, et d'autres variables comme la composition des plantes (e.g., le contenu en protéines) et leur disponibilité doivent aussi être considérées.

Mots clés: caribou, cypéracées, digestibilité, fermentation, in vitro, lichens, nutrition, Québec, recherche de nourriture, Rangifer tarandus

\section{INTRODUCTION}

The Rivière George caribou herd in northern Québec and Labrador increased at an annual rate of more than $10 \%$ in the period from 1954 to 1986 , and seems to have stabilized at more than 680000 individuals thereafter (Messier et al., 1988; Hearn et al., 1990; Couturier et al., 1996; Crête et al.,
1996). However, a decrease in adult survival, female fecundity, and autumn cow:calf ratios in recent years suggests that the population may now be declining (Couturier et al., 1996; Crête et al., 1996).

The herd occupies a range of about $600000 \mathrm{~km}^{2}$ and migrates from the wintering areas of forest-tundra and boreal forest south and west of Kuujjuaq, to the calving ground

${ }^{1}$ Département de biologie and Centre d'études nordiques, Université Laval, Sainte-Foy, Québec G1K 7P4, Canada; present address: Groupe de recherche en écologie, nutrition et énergétique, Département de biologie, Université de Sherbrooke, Sherbrooke, Québec J1K 2R1, Canada; steeve.cote@ callisto.si.usherb.ca

(C) The Arctic Institute of North America 
situated on the tundra plateaus of the Rivière George (Messier et al., 1988; Crête et al., 1990a). For most North American ungulate species, winter habitats are normally more critical, in terms of forage availability and quality, than summer habitats (Messier et al., 1988). However, studies on the Rivière George caribou herd have suggested that forage limitations in the summer range (calving ground) could be the main factor of population regulation (Messier et al., 1988; Crête et al., 1990a; Crête and Huot, 1993; Crête et al., 1996). The summer range, which represents only about $15 \%$ of the annual range (Messier et al., 1988), has deteriorated over the last 15 years from overgrazing (Crête et al., 1990a; Manseau et al., 1996). Presumably as a result of this deterioration, females have recently begun to leave their winter range later and stay for a shorter period on the calving ground (Crête et al., 1990a, 1996). In addition, low fat reserves of females during the first month of lactation and in the fall, combined with low calf growth, suggest that caribou are nutritively stressed during summer (Huot, 1989; Crête and Huot, 1993; Manseau, 1996). In this context, caribou-habitat relationships may be critical in summer, and studies on the interactions between the caribou and its summer food are needed.

Assessment of factors influencing the foraging ecology of large herbivores is important because the nutritional status of individuals is known to affect their growth rate, body size, and perhaps their reproduction (Klein, 1982; Huot, 1989; Robbins, 1993; Yamauchi and Iwasa, 1995). The diet choice of northern ungulates is strongly linked to plant phenology (Kuropat and Bryant, 1980; White and Trudell, 1980; Skogland, 1984; Forchhammer and Boomsma, 1995) and is influenced by the relative digestibility of plants (Person, 1975; White et al., 1975; Thomas and Kroeger, 1980; White and Trudell, 1980). When plant availability is accounted for, ruminants may be able to select the most digestible plant species (Thomas and Kroeger, 1980; White and Trudell, 1980). However, other factors such as protein content may also affect diet choice (Skogland, 1984). An understanding of the variables affecting digestibility is critical when assessing what factors are driving the herbivores' diet choice and can provide valuable insights for understanding herbivore foraging strategies. This understanding is particularly important for a population such as the Rivière George caribou herd, which is thought to be regulated by summer forages (Messier et al., 1988). Therefore, one goal of this study was to assess whether plant digestibility can explain the summer diet choice of the Rivière George caribou herd reported in earlier studies (Gauthier et al., 1989; Crête et al., 1990a).

Several authors have reported important variability in the digestibility of forages eaten by ungulates (Person, 1975; Palmer and Cowan, 1980; Thomas et al., 1984; Pehrson and Faber, 1994). High variability in plant digestibility has been reported among sites, plant species, seasons, fermentation time, and methods used to estimate digestibility (Person et al., 1980; Thomas and Kroeger, 1980, 1981; Brooks and Urness, 1984; Thomas et al., 1984). This high variability underlines the need to document digestibility values when studying new ungulate - habitat ecosystems and to use standard methods to determine digestibility. One way to promote a standard method is to use the rumen fluid of an easily accessible animal on a controlled diet, such as a domestic ruminant. Therefore, another objective of this study was to determine the effect of fermentation time and plant collection date on the relative digestibility of lichens, Cyperaceae, and shrubs eaten by the Rivière George caribou herd during summer, using a standard inoculum donor, a Holstein cow.

\section{MATERIAL AND METHODS}

Plant specimens were collected at various sites on the summer range of the Rivière George caribou herd in northern Québec $\left(58^{\circ} \mathrm{N}, 65^{\circ} \mathrm{W}\right)$. The area is characterized by tundra plateaus dominated by lichens, mosses, graminoids and prostrated shrubs (Messier et al., 1988; Crête et al., 1990a). I analysed the plant species most commonly found in the rumen contents of caribou collected in the same area during summer (Gauthier et al., 1989; Crête et al., 1990a). I sampled the live part (the top 5-10 cm) of five species of lichens; two species of Cyperaceae (Eriophorum angustifolium, Carex rariflora), and the leaves of two deciduous shrubs (Betula glandulosa, Vaccinium uliginosum). The two species of shrubs appeared particularly important, because they were found in all 12 animals collected in the summer range (Gauthier et al., 1989; Crête et al. 1990a). Lichens were collected on 20-21 June 1992 and vascular plants between 5 July and 6 August 1992 , i.e., over the complete period when caribou used the summer range during that year. Plants were oven-dried in the field at $45^{\circ} \mathrm{C}$ for about $24 \mathrm{~h}$, and stored (Mould and Robbins, 1981). They were further dried at the same temperature in the laboratory for $24 \mathrm{~h}$ and ground in a Wiley mill (40 mesh) (Thomas et al., 1984). I mixed samples of 15-20 individual plants in digestibility trials to minimize the potential effects of inter-individual variability.

I used the Tilley and Terry (1963) method (modified by Goering and Van Soest, 1970) to evaluate in vitro dry matter disappearance (IVDMD) of forages. This technique has been widely used for both domestic and wild herbivores because of the difficulty involved in performing digestion studies in vivo (Nocek, 1988). Briefly, the method consists of fermenting $0.5 \mathrm{~g}$ of substrate at $39^{\circ} \mathrm{C}$ with $10 \mathrm{~mL}$ of rumen fluid, $40 \mathrm{~mL}$ of buffer solution, and $2 \mathrm{~mL}$ of reducing solution. Following Thomas et al. (1984), I slightly modified Tilley and Terry's protocol. I added urea $(126 \mathrm{mg} / \mathrm{mL})$ to the solution to ensure that nitrogen was not a limiting factor, because ruminants normally recycle nitrogen when it occurs at low concentration (Wales et al., 1975; Cochran et al., 1986). Also, following Donefer et al. (1960) and Johnson (1966), I added biotine $(10 \mu \mathrm{g} / \mathrm{mL})$ and valeric acid $(5 \mathrm{mg} / \mathrm{mL})$ to ensure the survival of rumen cellulolytic bacteria.

I used inoculum of a rumen-fistulated Holstein cow that was fed good silage once daily. Inoculum was collected at the same time each day, 2 to 3 hours before feeding. It was obtained with a vacuum pump and filtered inside the rumen by means of a hose fitted with a filter. The rumen fluid was 
placed in a $40^{\circ} \mathrm{C}$ prewarmed, insulated container, and one teaspoon of $\mathrm{FeS}$ was added to ensure a reduced environment for microorganisms during transportation to the laboratory (Palmer and Cowan, 1980; Mbwile and Udén, 1991). The time from collection of the inoculum to initiation of fermentation in $125 \mathrm{~mL}$ flasks was about 1 hour.

In each digestion trial, I ran five different samples and a control, the Whatman filter paper \#1 (100\% cellulose), in triplicate (Clary et al., 1988). All plants were digested for 12, 24 and $48 \mathrm{~h}$ periods, which approximately covered the range of natural fermentation times during summer (Person, 1975; Jiang and Hudson, 1996). Independent plant samples were used for the different fermentation periods. After the digestion, $1 \mathrm{~mL}$ of toluene was added to the solution as a preservative (Goering and Van Soest, 1970). Samples were stored at temperatures between $0^{\circ}$ and $4^{\circ} \mathrm{C}$ for 2 to 6 weeks, and true digestibility was determined with the neutral-detergent fibre (NDF) procedure (Goering and Van Soest, 1970). The neutral detergent was added to the residuals of fermentation. The IVDMD, corrected for percentage of dry matter, could then be calculated as:

$$
\text { IVDMD }=100-\mathrm{NDF}
$$

Effects of plant phenology (collection date), species, and fermentation period $(12,24$, and $48 \mathrm{~h}$ ) on IVDMD were tested with two-way ANOVAs (Sokal and Rohlf, 1981). Plant samples collected at intervals of approximately 2 weeks were used to assess the effects of plant phenology on IVDMD. Lichens were collected only once, because their composition and digestibility have been reported to be relatively stable over seasons (Longton, 1988). A one-way ANOVA was used to compare the IVDMD of Cyperaceae and shrub species (for the 24 and $48 \mathrm{~h}$ trials): the fact that no IVDMD values were available for the $12 \mathrm{~h}$ fermentation of $B$. glandulosa precluded the use of a two-way ANOVA. Post-hoc multiple comparisons were conducted with a Scheffé F-test (Sokal and Rohlf, 1981). Differences reported were considered statistically significant at $p<0.05$, and the IVDMD values are presented as the average \pm SD.

\section{RESULTS}

In vitro dry matter digestibility of both species of Cyperaceae was higher for long fermentation periods ( $48 \mathrm{~h})$ than for short periods (Fig. 1) (E. angustifolium, $F_{2,10}=31.1$, $p<0.0001 ;$ C. rariflora, $\left.F_{2,10}=42.3, p<0.0001\right)$. Specimens collected earlier during the summer were also more digestible than those collected later (Fig. 1) (E. angustifolium, $F_{1,10}=$ $18.2, p=0.002 ;$ C. rariflora, $\left.F_{1,10}=91.8, p<0.0001\right)$. Furthermore, the interaction between fermentation period and plant collection date was significant for both species (E. angustifolium, $F_{2,10}=5.6, p=0.02 ; C$. rariflora,$F_{2,10}=9.4$, $p=0.005$ ), indicating that early fermentation rates (under $24 \mathrm{~h}$ ) varied over the summer. Plants collected early during the summer attained maximum digestibility levels after $24 \mathrm{~h}$,

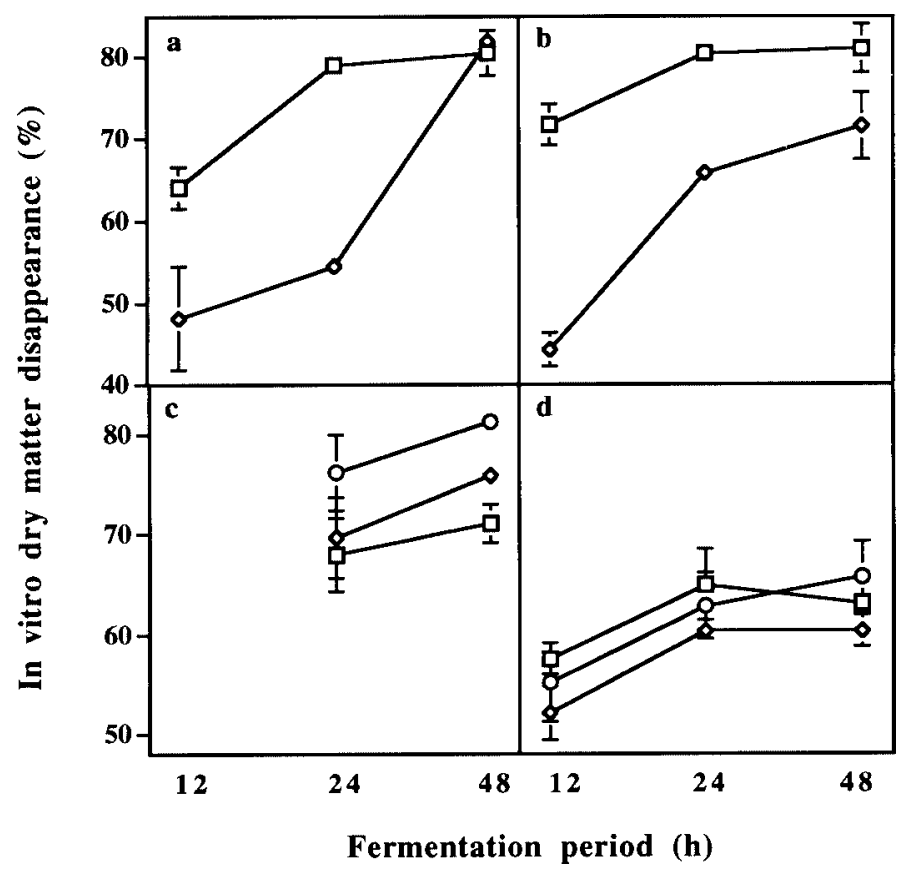

FIG. 1. In vitro dry matter disappearance (\% \pm SD) of a) Eriophorum angustifolium, b) Carex rariflora, c) Betula glandulosa, and d) Vaccinium uliginosum collected on the summer range of the Rivière George caribou herd, northern Québec, and fermented for 12, 24, and $48 \mathrm{~h}$. Circles represent plants collected at the onset of the growing season; squares, plants collected at peak biomass; and diamonds, plants collected at the end of the growing season.

while those collected later had IVDMD 5-25\% higher after $48 \mathrm{~h}$ than after $24 \mathrm{~h}$ (Fig. 1).

Similarly, the IVDMD of shrubs increased with a longer fermentation period (Fig. 1) (B. glandulosa, $F_{1,12}=13.0, p=$ $0.004 ; V$. uliginosum, $\left.F_{2,18}=26.8, p<0.0001\right)$ and decreased with the later collection date of leaves (Fig. 1) (B. glandulosa, $F_{2,12}=16.3, p=0.0004 ; V$. uliginosum, $\left.F_{2,18}=6.9, p=0.006\right)$. In contrast to Cyperaceae, the shrubs showed no change in fermentation rate over the summer.

Among lichens, Alectoria ochroleuca and Cetraria spp. were more digestible than Cladina rangiferina, Cladina stellaris and Stereocaulon paschale (Fig. 2$)\left(F_{4,28}=593.1\right.$, $p<0.0001)$. Fermentation period did not affect the IVDMD of lichens $\left(F_{2,28}=2.8, p=0.08\right)$.

Comparison of the IVDMD of the four species of vascular plants collected on similar dates revealed that the Cyperaceae were more digestible than the shrubs in mid-July $\left(F_{3,19}=37.4\right.$, $p<0.0001)$ but not in early August $\left(F_{3,17}=3.1, p=0.06\right)$ (Scheffé test). The significant interactions between species and date showed that the IVDMD values of the four species varied differently during the summer (Fig. 1$)\left(24 \mathrm{~h}: F_{3,14}=7.3\right.$, $p=0.003 ; 48$ h: $\left.F_{3,14}=6.1, p=0.007\right)$.

\section{DISCUSSION}

I used rumen inoculum from a cow rather than from a caribou because in several studies of digestibilities of forages utilized by wild herbivores, the use of a domestic ruminant as the inoculum source had given very reliable results (Palmer 


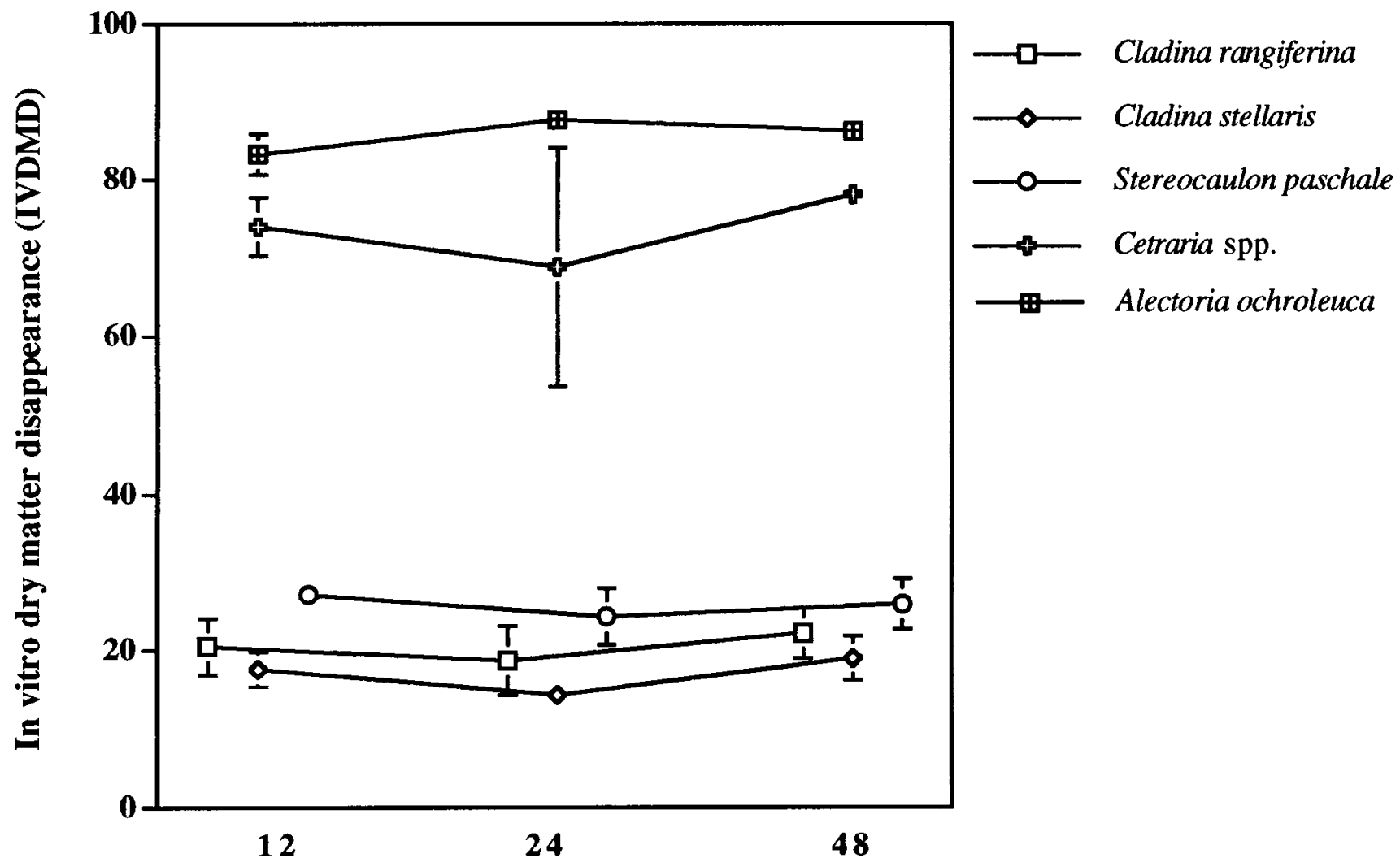

Fermentation period (h)

FIG. 2. Effect of fermentation period on in vitro dry matter disappearance $(\% \pm \mathrm{SD})$ of lichens collected in the summer range of the Rivière George caribou herd, northern Québec (1992).

et al., 1976; Palmer and Cowan, 1980; Welch et al., 1983; Brooks and Urness, 1984; Crawford and Hankinson, 1984). A single domestic inoculum source also reduces the variability of the rumen fluid caused by the use of several donors feeding on different diets (Clary et al., 1988; Pehrson and Faber, 1994). This method is particularly applicable when one is interested in making comparisons of digestibility of forages and fermentation time (as in this study), rather than in studying energy budget (Brooks and Urness, 1984; Campa et al., 1984). Even though cow inoculum was used, the IVDMD values of the different plant species analysed in this study were in the range of values previously obtained using caribou inoculum (Thomas and Kroeger, 1980, 1981; Thomas et al., 1984; Rominger and Robbins, 1996). Also, difficulties in obtaining sufficient volumes of rumen fluid from wild animals (Crawford and Hankinson, 1984; Nocek, 1988) and logistical problems involved in running digestibility trials in the field are greatly reduced when using a domestic ruminant.

I found that the IVDMD of Cyperaceae and shrubs generally decreased as summer progressed. A seasonal decline in IVDMD has often been reported in the literature and usually indicates a decrease in plant quality (Gaare and Skogland, 1975; Person, 1975; White et al., 1981). Plant fibre content and less digestible fibre types (e.g., lignin, cellulose) normally increase over the growing season, thus reducing digestibility (White et al., 1975; Skogland, 1984; Robbins, 1993).
Higher IVDMD values of Cyperaceae and shrubs with increasing fermentation periods were consistent with earlier results obtained for plant species eaten by caribou (Thomas and Kroeger, 1980; Thomas et al., 1984). Interestingly, however, the effects of fermentation time for the Cyperaceae varied according to plant phenology. Plants collected early in the summer attained maximum IVDMD values in shorter fermentation periods than those collected later. Again, these results are likely due to the fibre increase in graminoid tissues with the advent of summer (White et al., 1975; Jones and Wilson, 1987).

Although all species of lichens studied are used by caribou in summer (Crête et al., 1990a), the greater IVDMD of A. ochroleuca and Cetraria spp. compared to the two species of Cladina and $S$. paschale could be partly explained by the different fibre content (and type) of those species. A. ochroleuca and Cetraria spp. have fibre contents of about 2\% (Solberg, 1967), while Cladina spp. and S. paschale values range from 18\% to 32\% (Solberg, 1967; Pullianen, 1971). The low IVDMD results for Cladina spp. and S. paschale (Fig. 2) are surprising because the important amounts of these species found in the summer diet suggest high IVDMD values (Gauthier et al., 1989; Crête et al., 1990a). The high representation of these species in the caribou diet (Crête et al., 1990a) may be due to their greater availability and accessibility in the field (Skogland, 1984; 
Lundberg and Palo, 1993). Although virtually all lichen species have been overused in the Rivière George area (Manseau et al., 1996), Cladina spp. are about six times more available than A. ochroleuca and Cetraria spp. together (Crête et al., 1990b). In contrast to the results of studies by Thomas and Kroeger (1981) and Thomas et al. (1984), the IVDMD of lichens did not increase with fermentation period, likely because my fermentation intervals were shorter than those used in the earlier studies. In fact, those studies mainly reported differences between trials of $15-16 \mathrm{~h}$ and $120-180$ $\mathrm{h}$; durations 68 to $129 \mathrm{~h}$ longer than my longest interval. Microbacterial type and concentration likely differed between the Thomas and Kroeger (1981) and Thomas et al. (1984) trials (caribou inoculum) and my trials (cow inoculum). Therefore, one would have predicted that lichen samples digested with cow inoculum would have lower IVDMD values, since caribou inoculum may contain bacteria specialized in the digestion of lichens (Nieminen et al., 1980). However, my IVDMD values for the different species of lichens were in the range of the values previously obtained for caribou (Thomas and Kroeger, 1980, 1981; Thomas et al. 1984).

Cyperaceae were more digestible than shrubs in mid-July but not in early August. The higher IVDMD values of graminoids compared to shrubs in mid-July were unexpected, because caribou appeared to eat more shrub leaves than graminoid-type plants during this period (Gauthier et al., 1989; Crête et al., 1990a). Moreover, Manseau (1996) reported higher $\%$ NDF (cell walls) for Carex spp. $(\sim 60 \%)$ than for Vaccinium spp. ( 30\%) and B. glandulosa (20\%) during the same period and in the same study area, suggesting that shrubs should be even more digestible than graminoids. However, Manseau (1996) also found that shrubs in the Rivière George area had more phenolic constituents than graminoid-type plants during the same period (Vaccinium spp. and B. glandulosa: $\sim 18 \%$; Carex spp. and E. angustifolium: $\sim 5 \%)$. Phenolic compounds bind with proteins and usually reduce digestibility (Mould and Robbins, 1982; Kuropat and Bryant, 1983; Palo, 1985). This effect may explain the lower IVDMD of shrubs compared to the Cyperaceae in mid-July. However, it does not explain why caribou seem to eat more shrub leaves, especially of B. glandulosa, during this period (Gauthier et al., 1989; Crête et al., 1990a). A possible reason is that caribou, especially females facing high costs of lactation, select the leaves of B. glandulosa because they contain more protein than graminoid-type plants, and much more than lichens (Pruitt, 1979; Crête et al., 1990a; Manseau, 1996). Unfortunately, it is not possible to infer if this continues into August and early fall, because the diet of the Rivière George caribou herd during this later period is not known. An alternative explanation could be that $B$. glandulos $a$ and other shrubs are used because they appear more abundant than graminoids in the Rivière George area (Skogland, 1984; Manseau, 1996; Toupin et al., 1996). These results indicate that digestibility values alone cannot explain the summer diet that has been previously reported for the Rivière George caribou (Gauthier et al., 1989; Crête et al., 1990a). In order to maximize energy intake and fulfill its needs for growth, lactation, and tissue regeneration, a caribou would profit by feeding on plant species that represent the best compromise between digestibility-protein content and availability (Lundberg and Palo, 1993). To test the hypothesis that caribou, and other ungulates, can select plant species according to their relative digestibilities (Thomas and Kroeger, 1980; White and Trudell, 1980), further studies should concentrate on simultaneously measuring diet, the relative abundance of species, and plant constituents (e.g., fibre, protein, phenols) during the vegetation growing season.

\section{ACKNOWLEDGEMENTS}

I am indebted to J. Huot for his involvement during all stages of this project. I thank G. Picard for help in the laboratory analyses and M. Manseau for permitting access to vegetation samples. I am grateful to V. Girard and M. Tremblay from the Agriculture Canada Research Station at Deschambault (Québec) for providing access to a rumen-fistulated cow. A. Garneau, M. Poulin, and M. Duchesne helped with the rumen fluid collection. M. Crête, J. Edmonds, M. Festa-Bianchet, J. Huot, P. Lundberg, J.-P. Ouellet, K.G. Smith and an anonymous referee kindly reviewed an earlier draft of this manuscript. This study was financed by the Natural Sciences and Engineering Research Council of Canada (operating grant to J. Huot and Scholarships to S.D.C.), the Centre d'études nordiques (Université Laval), Hydro-Québec, and the Ministère de l'Environnement et de la Faune du Québec.

\section{REFERENCES}

BROOKS, J., III, and URNESS, P.J. 1984. Comparison of in vivo and in vitro digestibility of forages by elk. Journal of Animal Science 58:963-970.

CAMPA, H., III, WOODYARD, D.K., and HAUFLER, J.B. 1984. Reliability of captive deer and cow in vitro digestion values in predicting wild deer digestion levels. Journal of Range Management 37:468-470.

CLARY, W.P., WELCH, B.L., and BOOTH, G.D. 1988. In vitro digestion experiments: Importance of variation between inocula donors. Journal of Wildlife Management 52:358-361.

COCHRAN, R.C., ADAMS, D.C., WALLACE, J.D., and GALVEAN, M.L. 1986. Predicting digestibility of different diets with internal markers: Evaluation of four potential markers. Journal of Animal Science 63:1476-1483.

COUTURIER, S., COURTOIS, R., CRÉPEAU, H., RIVEST, L.P., and LUTTICH, S.N. 1996. Calving photocensus of the Rivière George caribou herd: Comparison with an independent census. Rangifer, Special Issue 9:283-296.

CRAWFORD, H.S., and HANKINSON, D.H. 1984. White-tailed deer vs. bovine inocula for in vitro digestibilities. Journal of Wildlife Management 48:649-652.

CRÊTE, M., and HUOT, J. 1993. Regulation of a large herd of migratory caribou: Summer nutrition affects calf growth and body reserves of dams. Canadian Journal of Zoology 71: 2291-2296. 
CRÊTE, M., HUOT, J., and GAUTHIER, L. 1990a. Food selection during early lactation by caribou calving on the tundra in Quebec. Arctic 43:60-65.

CRÊTE, M., MORNEAU, C., and NAULT, R. 1990b. Biomasse et espèces de lichens terrestres disponibles pour le caribou dans le nord du Québec. Canadian Journal of Botany 68:2047-2053.

CRÊTE, M., COUTURIER, S., HEARN, B.J., and CHUBBS, T.E. 1996. Relative contribution of decreased productivity and survival to recent changes in the demographic trend of the Rivière George caribou herd. Rangifer, Special Issue 9:27-36.

DONEFER, E., CRAMPTON, E.W., and LLOYD, L.E. 1960. Prediction of nutritive value index of a forage from in vitro rumen fermentation data. Journal of Animal Science 19:545-552.

FORCHHAMMER, M.C., and BOOMSMA, J.J. 1995. Foraging strategies and seasonal diet optimization of muskoxen in West Greenland. Oecologia 104:169-180.

GAARE, E., and SKOGLAND, T. 1975. Wild reindeer food habits and range use at Hardangervidda. In: Wielgolaski, F.E., ed. Fennoscandian tundra ecosystems. New York: Springer-Verlag. 195-205.

GAUTHIER, L., NAULT, R., and CRÊTE, M. 1989. Variations saisonnières du régime alimentaire des caribous du troupeau de la rivière George, Québec nordique. Naturaliste canadien 116:101-112.

GOERING, H.K., and VAN SOEST, P.J. 1970. Forage fibre analyses. Agriculture Handbook No. 379. Washington, D.C.: United States Government Printing Office.

HEARN, B.J., LUTTICH, S.N., CRÊTE, M., and BERGER, M.B. 1990. Survival of radio-tagged caribou (Rangifer tarandus caribou) from the George River Herd, Nouveau-QuébecLabrador. Canadian Journal of Zoology 68:276-283.

HUOT, J. 1989. Body composition of the George River caribou herd (Rangifertarandus caribou) in fall and late winter. Canadian Journal of Zoology 67:103-107.

JIANG, Z., and HUDSON, R.J. 1996. Digestive responses of wapiti Cervus elaphus canadensis to seasonal forages. Acta Theriologica 41:415-423.

JOHNSON, R.R. 1966. Techniques and procedures for in vitro and in vivo rumen studies. Journal of Animal Science 25:855-875.

JONES, D.I.H., and WILSON, A. 1987. Nutritive quality of forage. In: Hacker, J.B., and Ternouth, J.H., eds. The nutrition of herbivores. Orlando: Academic Press. 65-89.

KLEIN, D.R. 1982. Factors influencing forage quality for reindeer and caribou. In: Peek, J.M., and Dalke, P.D., eds. Wildlifelivestock relationship Symposium No. 10. Moscow, Idaho: University of Idaho. 383-393.

KUROPAT, P., and BRYANT, J. 1980. Forage use by parturient and post parturient caribou on the Utukok calving grounds in northwestern Alaska. In: Reimers, E., Gaare, E., and Skjenneberg, S., eds. Proceedings of the 2nd International Reindeer and Caribou Symposium. Trondheim: Direktoratet for vilt og ferskvannsfisk. 64-70.

- 1983. Digestibility of caribou summer forage in arctic Alaska in relation to nutrient, fibre, and phenolic constituents. Acta Zoologica Fennica 175:51-52.

LONGTON, R.E. 1988. The biology of polar bryophytes and lichens. Cambridge: Cambridge University Press.
LUNDBERG, P., and PALO, R.T. 1993. Resource use, plant defenses, and optimal digestion in ruminants. Oikos 68:224-228.

MANSEAU, M. 1996. Relations réciproques entre les caribous et la végétation des aires d'été: Le cas du troupeau de la Rivière George. Ph.D. Thesis. Université Laval, Sainte-Foy, Québec.

MANSEAU, M., HUOT, J., and CRÊTE, M. 1996. Effects of summer grazing by caribou on composition and productivity of vegetation: Community and landscape level. Journal of Ecology 84:503-513.

MBWILE, R.P., and UDÉN, P. 1991. Comparison of laboratory methods on precision and accuracy of predicting forage organic matter digestibility. Animal Feed Science and Technology 32:243-251.

MESSIER, F., HUOT, J., LE HENAFF, D., and LUTTICH, S. 1988. Demography of the George River caribou herd: Evidence of population regulation by forage exploitation and range expansion. Arctic 41:279-287.

MOULD, E., and ROBBINS, C. 1981. Evaluation of detergent analysis in estimating nutritional value of browse. Journal of Wildlife Management 45:937-947.

. 1982. Digestive capabilities in elk compared to whitetailed deer. Journal of Wildlife Management 46:22-29.

NIEMINEN, M., KELLOKUMPU, S., VÄRYHYNEN, P., and HYVÄRINEN, H. 1980. Rumen function in reindeer. In: Reimers, E., Gaare, E., and Skjenneberg, S., eds. Proceedings of the 2nd International Reindeer and Caribou Symposium. Trondheim: Direktoratet for vilt og ferskvannsfisk. 213-223.

NOCEK, J.E. 1988. In situ and other methods to estimate ruminal protein and energy digestibility: A review. Journal of Dairy Science 71:2051-2069.

PALMER, W.L., and COWAN, R.L. 1980. Estimating digestibility of deer foods by an in vitro technique. Journal of Wildlife Management 44:469-472.

PALMER, W.L., COWAN, R.L., and AMMANN, A.P. 1976. Effect of inoculum source on in vitro digestion of deer foods. Journal of Wildlife Management 40:301-307.

PALO, R.T. 1985. Chemical defence in birches: Inhibition of digestibility in ruminant by phenolic extracts. Oecologia 68:10-14.

PEHRSON, Å., and FABER, W.E. 1994. Individual variation of in vitro dry matter digestibility in moose. Journal of Range Management 47:392-394.

PERSON, S.J. 1975. Digestibility of indigenous plants utilized by Rangifertarandus. Ph.D. Thesis. University of Alaska, Fairbanks.

PERSON, S.J., PEGAU, R.E., WHITE, R.G., and LUICK, J.R. 1980. In vitro and nylon-bag digestibilities of reindeer and caribou forages. Journal of Wildlife Management 44:613-622.

PRUITT, W.O., Jr. 1979. A numerical "snow index" for reindeer (Rangifer tarandus) winter ecology (Mammalia, Cervidae). Annales Zoologici Fennici 16:271-280.

PULLIANEN, E. 1971. Nutritive values of some lichens used as food by reindeer in northeastern Lapland. Annales Zoologici Fennici 8:385-389.

ROBBINS, C.T. 1993. Wildlife feeding and nutrition. 2nd ed. New York: Academic Press.

ROMINGER, E.M., and ROBBINS, C.T. 1996. Generic preference and in vivo digestibility of alectorioid arboreal lichens by woodland caribou. Rangifer, Special Issue No. 9:379-380. 
SKOGLAND, T. 1984. Wild reindeer foraging-niche organization. Holarctic Ecology 7:345-379.

SOKAL, R.R., and ROHLF, F.J. 1981. Biometry. 2nd ed. San Francisco: W.H. Freeman \& Co.

SOLBERG, Y. J. 1967. Studies on the chemistry of lichens. IVThe chemical composition of some Norwegian lichen species. Annales Botanici Fennici 4:29-34.

THOMAS, D.C., and KROEGER, P. 1980. In vitro digestibilities of plants in rumen fluids of Peary caribou. Arctic 33:757-767.

- 1981. Digestibility of plants in ruminal fluids of barrenground caribou. Arctic 34:321-324.

THOMAS, D.C., KROEGER, P., and HERVIEUX, D. 1984. In vitro digestibilities of plants utilized by barren-ground caribou. Arctic 37:31-36.

TILLEY, J.M.A., and TERRY, R.A. 1963. A two-stage technique for the in vitro digestion of forage crops. Journal of the British Grasslands Society 18:104-111.

TOUPIN, B., HUOT, J., and MANSEAU, M. 1996. Effect of insect harassment on the behaviour of the Rivière George caribou. Arctic 49:375-382.

WALES, R.A., MILLIGAN, L.P., and McEWAN, E.H. 1975. Urea recycling in caribou, cattle and sheep. In: Luick, J.R., Lent, P.C.,
Klein, D.R., and White, R.G., eds. Proceedings of the 1st International Reindeer and Caribou Symposium. University of Alaska Biological Paper Special Report 1:297-307.

WELCH, B.L., PEDERSEN, J.C., and CLARY, W.P. 1983. Ability of different rumen inocula to digest range forages. Journal of Wildlife Management 47:873-877.

WHITE, R.G., and TRUDELL, J. 1980. Habitat preference and forage consumption by reindeer and caribou near Atkasook, Alaska. Arctic and Alpine Research 12:511-529.

WHITE, R.G., BUNNELL, F.L., GAARE, E., SKOGLAND, T., and HUBERT, G. 1981. Ungulates on arctic ranges. In: Bliss, L.C., Cragg, J.B., Heal, D.W., and Moore, J.J., eds. Tundra ecosystems: A comparative analysis. Cambridge: Cambridge University Press. 397-483.

WHITE, R.G., THOMSON, B.R., SKOGLAND, T., PERSON, S.J., RUSSELL, D.E., HOLLEMAN, D.F., and LUICK, J.R. 1975. Ecology of caribou at Prudhoe Bay, Alaska. In: Brown, J., ed. Ecological investigations of the tundra biome in the Prudhoe Bay region, Alaska. University of Alaska Biological Paper Special Report 2:151-187.

YAMAUCHI, A., and IWASA, Y. 1995. Coupling of fermentation and foraging strategies of herbivorous mammals. Journal of Theoretical Biology 172:1-11. 